\title{
KEMAMPUAN MENULIS TEKS KARANGAN NARASI SISWA KELAS X SMK NEGERI 03 MODEL INVEST KOTA BENGKULU
}

\author{
Prisna Destia ${ }^{1}$, Padi Utomo ${ }^{2}$, dan M. Arifin ${ }^{3}$ \\ ${ }^{1,2,3}$ Program Studi Pendidikan Bahasa dan Sastra Indonesia \\ Jurusan Pendidikan Bahasa dan Seni \\ FKIP Universitas Bengkulu \\ destiaprisna@yahoo.com
}

\begin{abstract}
Abstrak
Tujuan penelitian ini untuk mendeskripsikan kemampuan menulis teks karangan narasi siswa kelas X SMK Negeri 03 Model Invest Kota Bengkulu. Metode yang digunakan dalam penelitian ini adalah metode deskriptif dengan pendekatan kuantitatif. Penelitian ini dilakukan di SMK Negeri 03 Model Invest Kota Bengkulu. Teknik yang digunakan pengumpulan data dalam adalah teknik tes. Teknik analisis data yang digunakan analisis deskriptif dengan pendekatan kuantitatif sederhana, penyajian data, dan penarikan kesimpulan. Hasil penelitian ini menunjukkan bahwa kemampuan menulis siswa kelas X SMK Negeri 03 Model Invest Kota Bengkulu adalah kurang dengan memperoleh persentase 55,80 . kemampuan menulis siswa kelas X SMK Negeri 03 Model Invest Kota Bengkulu secara khusus dari aspek isi memperoleh persentase 17.82 dengan kriteria buruk, aspek struktur teks memperoleh persentase 12,24 dengan kriteria buruk, aspek kosakata memperoleh persentase 10,39 dengan kriteria buruk sekali, aspek kalimat memperoleh persentase 9,15 dengan kriteria buruk sekali, aspek mekanik memperoleh persentase 5,17 dengan kriteria buruk sekali.
\end{abstract}

\section{Kata Kunci: Kemampuan menulis, teks karangan narasi.}

\begin{abstract}
The purpose of this study to describe the ability to write text essay narrative students class $X$ SMK Negeri 03 Model Invest Kota Bengkulu. The method used in this research is descriptive method with quantitative approach. This research was conducted at SMK Negeri 03 Model Invest Kota Bengkulu. The technique used in data collection is a test technique. Data analysis techniques used descriptive analysis with a simple quantitative approach, data presentation, and conclusion. The results of this study indicate that the ability to write class $X$ students SMK Negeri 03 Model Invest Bengkulu City is less by obtaining a percentage of 55.80. The ability to write class $X$ students SMK Negeri 03 Model Invest City of Bengkulu specifically from the aspect of the contents obtained percentage 17.82 with bad criteria, text structure aspects get 12.24 percentage with bad criteria, vocabulary aspect obtained 10.39 percentage with bad criteria, sentence aspect Get the percentage of 9.15 with very bad criteria, mechanical aspect earn 5.17 percentage with very bad criterion,
\end{abstract}

Keywords: Writing ability, text of authorship. 


\section{PENDAHULUAN}

Pembelajaran perlu dikembangkan dengan menggunakan desain pembelajaran yang tepat. Pembelajaran yang harus diterapkan ialah pembelajaran yang mendorong peserta didik untuk mencari tahu bukan pembelajaran yang memberi tahu peserta didik. Pembelajaran yang mendorong siswa mencari tahu merupakan pembelajaran aktif dan konstruktif, siswa akan dibiasakan membangun pengetahuannya sendiri berdasarkan konteks nyata yang bermakna baginya Abidin (2013:17).

Pembelajaran bahasa Indonesia untuk jenjang Pendidikan Menengah Kelas $X$ disusun dengan berbasis teks, baik lisan maupun tulis, dengan menempatkan bahasa Indonesia sebagai wahana untuk mengekspresikan perasaan dan pemikiran. Siswa diharapkan mampu menggunakan dan memproduksi berbagai teks sesuai dengan tujuan dan fungsi sosialnya dalam Kurikulum K 13 Kemendikbud (2013).

Kurikulum K 13 merupakan kurikulum baru yang mulai diterapkan pada tahun 2013/2014. Kurikulum ini adalah pengembangan dari kurikulum yang telah ada sebelumnya, baik Kurikulum Berbasis Kompetensi yang telah dirintis pada tahun tahun 2004 maupun kurikulum Tingkat Satuan Satuan Pendidikan pada tahun 2006. Hanya saja yang menjadi titik tekan pada Kurikulum $\mathrm{K}$ 13 ini adalah adanya peningkatan dan kesimbangan soft skilll dan hard skill yang berupa sikap, keterampilan, dan pengetahuan Fadillah (2014:16).

Berdasarkan isi kurikulum K 13, guru dapat berkreasi dalam pembelajaran di kelas dengan kegiatan-kegiatan yang sesuai dan relevan yang bersumber dari lingkungan alam dan sosial. Perubahan kurikulum dari Kurikulum Tingkat Satuan. Pendidikan (KTSP) menjadi kurikulum K 13 menyajikan pembelajaran bahasa Indonesia berbasis teks yang di dalamnya mengandung unsur pengetahuan, baik lisan maupun tertulis. Dalam pembelajaran bahasa yang berbasiskan teks, bahasa Indonesia diajarkan bukan hanya sekedar pengetahuan, namun sebagai teks yang berfungsi sebagai sumber aktualisasi diri siswa pada konteks sosial-budaya akademis. Teks dipandang sebagai satuan bahasa yang bermakna secara kontekstual. Beberapa jenis teks dan istilah-istilah dalam kurikulum $\mathrm{K} 13$ masih asing terdengar di telinga siswa, bahkan guru Bahasa Indonesia itu sendiri . Kurangnya pengarahan dari pemerintah dan sumbersumber literatur membuat guru sulit untuk mempelajari jenis-jenis teks dan istilah dalam Kurikulum K 13 tersebut. Teks-teks yang disajikan dalam kurikulum $\mathrm{K} 13$, mirip dengan teks-teks yang dipelajari pada pelajaran Bahasa Inggris. Ragam teks tersebut memiliki fungsi, tujuan, dan struktur yang berbeda-beda pula. Salah satu jenis teks yang harus dikuasai Menulis Teks Karangan Narasi SMK Negeri 03 Model Invest Bengkulu.

Berkaitan dengan pentingnya pembelajaran mengenai teks karangan narasi, penulis pun tertarik melakukan penelitian pembelajaran teks karangan narasi yang ada di sekolah. Berdasarkan bahan ajar bidang studi Bahasa Indonesia kelas $X$ yang penulis amati, pembelajaran teks karangan narasi terdiri atas beberapa sub materi, seperti memahami teks karangan narasi, memproduksi teks karangan narasi, mengabstraksi teks karangan narasi, mengevaluasi proses karangan narasi, dan masih ada beberapa lainnya. Pada penelitian yang penulis lakukan, penulis membatasi masalah pada pembelajaran memahami teks karangan narasi. Pembatasan masalah ini penulis lakukan agar data penelitian dapat difokuskan pada satu materi pembelajaran. Selanjutnya, dalam hal menetapkan tempat penelitian, penulis memilih salah satu sekolah yang memiliki 
nilai akreditasi baik di Kota Bengkulu. Pemilihan sekolah yang memiliki akriditas baik dilakukan untuk mendukung pemerolehan data yang baik pula.

Berdasarkan hasil observasi dan wawancara kepada guru Bahasa Indonesia yang mengajar kelas di SMK Negeri 03 Model Invest Bengkulu, ada beberapa permasalahan yang ditemui oleh guru dalam pembelajaran menulis. Masalah yang dihadapi oleh guru yaitu, siswa menganggap kegiatan menulis belum optimal dilakukan, strategi pembelajaran yang digunakan oleh guru dalam mengajar menulis masih menggunakan strategi pembelajaran yang kurang menarik sehingga keaktifan siswa dalam proses pembelajaran masih kurang.

Berdasarkan hasil wawancara dengan guru menunjukkan bahwa pembelajaran tentang teks karangan narasi menjadi salah satu teks yang perlu perhatian khusus. Nilai siswa dalam menulis teks karangan narasi belum sesuai dengan pelaksanaan kurikulum $\mathrm{K} 13$ hal ini karena kurangnya kemampuan guru dalam melakukan pengajaran, pelaksanaan pembelajaran mengenai teks karangan narasi dalam pembelajaran kurikulum $\mathrm{K} 13$ meliputi kemampuan siswa dalam menulis teks karangan narasi yang meliputi isi, struktur tesk, kosakata, kalimat dan mekanik dalam teks karangan narasi. Pada pelaksanaan kegiatan pembelajaran bahasa Indonesia berdasarkan kurikulum, mencangkup 5 keterampilan dalam pendekatan saintifik yaitu mengamati, menanya, mengumpulkan informasi, menalar dan mengkomunikasikan yang menjadi inti dalam proses pembelajaran.

Menulis teks karangann narasi adalah suatu hal yang susah dilakukan dalam pembelajaran teks karangan narasi baru diterapkan dalam pembelajaran kurikulum $\mathrm{K}$ 13. Teks karangan narasi adalah teks yang berusaha menciptakan, mengisahkan, merangkaikan tindak-tanduk perbuatan manusia dalam sebuah peristiwa sacara kronologis atau yang berlangsung dalam kesatuan waktu ditambahkan pada pembelajaran kurikulum $\mathrm{K} 13$ ini pembelajaran bahasa Indonesia berbasis yang dilengkapi dengan struktur teks dan ciri kebahasaan. Penelitian mengenai teks karangan narasi di SMK Negeri 03 Model Invest Bengkulu belum pernah dilakukan karena sekolah ini baru menerapkan kurikulum K 13. Sehingga penulis tertarik ingin meneliti kemampuan siswa dalam menulis teks karangan narasi SMK Negeri 03 Model Invest Bengkulu.

Berdasarkan latar belakang di atas maka Tujuan penelitian ini untuk mengetahui kemampuan siswa dalam menulis teks karangan narasi SMK Negeri 03 Model Invest Bengkulu.

\section{METODE}

Metode yang digunakan dalam penelitian ini adalah metode deskriptif kuantitatif. Metode ini digunakan untuk mendapatkan suatu gambaran suatu keadaan yang berlangsung sekarang. Populasi dan penelitian adalah sebanyak 374 orang. Menurut Sugiyono (2012:118) "sampel adalah sebagian dari jumlah dan karakteristik yang dimiliki oleh populasi tersebut". Apabila kurang dari 100 lebih baik diambil semua hingga penelitiannya merupakan penelitian populasi. Sampel dalam penelitian ini adalah 79 orang responden.

Tes ini dijadikan sebagai tolak ukur untuk mengetahui kemampuan siswa dalam menulis teks karangan narasi. Tes ini digunakan untuk mengukur ada atau tidaknya serta besarnya kemampuan objek yang diteliti. Tes menulis teks karangan narasi ini berupa lembar tugas berisi perintah kepada siswa untuk menulis teks karangan narasi. Hasil tes berupa teks narasi. 


\section{HASIL DAN PEMBAHASAN}

Hasil analisis penelitian kemampuan siswa dalam menulis teks karangan narasi kelas X SMK Negeri 03 Model Invest Kota Bengkulu yang terdiri dari lima aspek yaitu: 1) isi, 2) struktur teks, 3) kosakata, 4) kalimat, 5) mekanik. Adapun berdasarkan instrument penelitian terdapat tiga topik dalam penulisan teks karangan narasi diantaranya: 1) jual beli sembako, 2) sengketa perkebunan warga, 3) kenaikan gaji karyawan mini market, terbagi menjadi: 46 siswa memilih topik karangan narasi jual beli sembako, 15 siswa memilih topik karangan narasi sengketa lahan perkebunan warga, dan 18 siswa memilih topik karangan narasi kenaikan gaji karyawan mini market. Dengan demikian, setiap topik yang dipilih siswa memiliki rata-rata nilai yaitu: topik karangan narasi jual beli sembako dengan rata-rata nilai 55,83 , topik karangan narasi sengketa lahan perkebunan warga dengan rata-rata nilai 55,6 , dan topik karangan narasi kenaikan gaji karyawan mini market dengan nilai rata-rata 50,22. Berikut pembahasan hasil analisis penelitian.

1. Kemampuan Siswa Dalam Menulis Teks Karangan Narasi Kelas X SMK Negeri 03 Model Invest Kota Bengkulu

Hasil perhitungan yang dianalisis diperoleh nilai rata-rata sebesar 55,80. Nilai tersebut bila dilihat pada kriteria penilaian termasuk dalam kategori sedang, karena terletak pada interval nilai 51-60. Dengan demikian, kemampuan siswa menulis dalam menulis teks karangan narasi kelas X SMK Negeri 03 Model Invest Kota Bengkulu dalam kategori sedang. Rincian kemampuan menulis siswa yaitu: 12 siswa termasuk dalam kategori nilai cukup, 54 siswa termasuk dalam kategori nilai sedang, 12 siswa termasuk dalam kategori nilai hampir sedang.

1. Kemampuan Siswa Dalam Menulis Teks Karangan Narasi Pada Aspek Isi
Kelas X SMK Negeri 03 Model Invest Kota Bengkulu

Mengetahui gambaran tentang kemampuan siswa dalam menulis teks karangan narasi aspek isi kelas $\mathrm{X}$ SMK Negeri 03 Model Invest Kota Bengkulu dari aspek isi menggunakan teknik deskriptif, yaitu menghitung rata-rata tingkat kemampuan.

Data kemampuan siswa dalam menulis teks karangan narasi aspek isi kelas X SMK Negeri 03 Model Invest Kota Bengkulu pada aspek isi dapat dilihat pada tabel 5. Hasil kemampuan subjek penelitian yaitu di peroleh nilai rata-rata sebesar 17,82 . Nilai tersebut bila dilihat pada kriteria penilaian aspek kesesuaian isi termasuk dalam kategori buruk, karena terletak pada interval nilai 11-20. Dengan demikian, kemampuan siswa dalam menulis teks karangan narasi kelas X SMK Negeri 03 Model Invest Kota Bengkulu pada aspek isi termasuk dalam kategori kurang.

Berdasarkan hasil perhitungan frekuensi pada tabel dan grafik dapat diketahui bahwa kemampuan siswa dalam menulis teks karangan narasi kelas $X$ SMK Negeri 03 Model Invest Kota Bengkulu pada aspek isi terbagi atas: 5 siswa termasuk kategori nilai kurang sekali, 74 siswa termasuk dalam kategori nilai buruk, dan tidak ada siswa termasuk dalam kategori nilai buruk sekali.

2. Kemampuan Siswa Dalam Menulis Teks Karangan Narasi Pada Aspek Struktur Teks Kelas X SMK Negeri 03 Model Invest Kota Bengkulu

Mengetahui gambaran tentang kemampuan siswa dalam menulis teks karangan narasi aspek struktur teks kelas $\mathrm{X}$ SMK Negeri 03 Model Invest Kota Bengkulu dari aspek struktur teks menggunakan teknik deskriptif, yaitu menghitung rata-rata tingkat kemampuan.

Data kemampuan siswa dalam menulis teks karangan narasi aspek 
struktur teks kelas X SMK Negeri 03 Model Invest Kota Bengkulu pada aspek struktur teks dapat dilihat pada tabel 6. Hasil kemampuan subjek penelitian yaitu di peroleh nilai rata-rata sebesar 12,24 Nilai tersebut bila dilihat pada kriteria penilaian aspek kesesuaian isi termasuk dalam kategori buruk, karena terletak pada interval nilai 11-20. Dengan demikian, kemampuan siswa dalam menulis teks karangan narasi kelas X SMK Negeri 03 Model Invest Kota Bengkulu pada aspek struktur teks termasuk dalam kategori buruk.

Berdasarkan hasil perhitungan frekuensi pada tabel dan grafik dapat diketahui bahwa kemampuan siswa dalam menulis teks karangan narasi kelas $X$ SMK Negeri 03 Model Invest Kota Bengkulu pada aspek struktur teks terbagi atas: 64 nilai siswa termasuk kategori nilai buruk, dan 15 siswa termasuk dalam kategori nilai buruk sekali.

3. Kemampuan Siswa Dalam Menulis Teks Karangan Narasi Pada Aspek Kosakata Kelas X SMK Negeri 03 Model Invest Kota Bengkulu

Mengetahui gambaran tentang kemampuan siswa dalam menulis teks karangan narasi aspek kosakata kelas $X$ SMK Negeri 03 Model Invest Kota Bengkulu dari aspek kosakata menggunakan teknik deskriptif, yaitu menghitung rata-rata tingkat kemampuan.

Data kemampuan siswa dalam menulis teks karangan narasi aspek kosakata kelas X SMK Negeri 03 Model Invest Kota Bengkulu pada aspek kosakata dapat dilihat pada tabel 7. Hasil kemampuan subjek penelitian yaitu di peroleh nilai rata-rata sebesar 10,39 . Nilai tersebut bila dilihat pada kriteria penilaian aspek kesesuaian isi termasuk dalam kategori buruk sekali, karena terletak pada interval nilai 1-10. Dengan demikian, kemampuan siswa dalam menulis teks karagan narasi kelas X SMK Negeri 03
Model Invest Kota Bengkulu pada aspek kosakata termasuk dalam kategori buruk sekali.

Berdasarkan hasil perhitungan frekuensi pada tabel dan grafik dapat diketahui bahwa kemampuan siswa dalam menulis teks karangan narasi kelas X SMK Negeri 03 Model Invest Kota Bengkulu pada aspek kosakata terbagi atas: 25 nilai siswa termasuk kategori nilai buruk, dan 54 siswa termasuk dalam kategori nilai buruk sekali.

4. Kemampuan Siswa Dalam Menulis Teks Karangan Narasi Pada Aspek Kalimat Kelas X SMK Negeri 03 Model Invest Kota Bengkulu

Mengetahui gambaran tentang kemampuan siswa dalam menulis teks karangan narasi aspek kalimat kelas X SMK Negeri 03 Model Invest Kota Bengkulu dari aspek kalimat menggunakan teknik deskriptif, yaitu menghitung rata-rata tingkat kemampuan.

Data kemampuan siswa dalam menulis teks karangan narasi aspek kalimat kelas X SMK Negeri 03 Model Invest Kota Bengkulu pada aspek kalimat dapat dilihat pada tabel 8. Hasil kemampuan subjek penelitian yaitu di peroleh nilai rata-rata sebesar 9,15 Nilai tersebut bila dilihat pada kriteria penilaian aspek kesesuaian isi termasuk dalam kategori buruk sekali, karena terletak pada interval nilai 1-10. Dengan demikian, kemampuan siswa dalam menulis teks karangan narasi kelas X SMK Negeri 03 Model Invest Kota Bengkulu pada aspek kalimat termasuk dalam kategori buruk sekali.

Berdasarkan hasil perhitungan frekuensi pada tabel dan grafik dapat diketahui bahwa kemampuan siswa dalam menulis teks karangan narasi kelas X SMK Negeri 03 Model Invest Kota Bengkulu pada aspek kalimat terbagi atas: 13 nilai siswa termasuk kategori nilai buruk, dan 
66 siswa termasuk dalam kategori nilai buruk sekali.

5. Kemampuan Siswa Dalam Menulis Teks Karangan Narasi Pada Aspek Mekanik Kelas X SMK Negeri 03 Model Invest Kota Bengkulu

Mengetahui gambaran tentang kemampuan siswa dalam menulis teks karangan narasi aspek mekanik kelas $\mathrm{X}$ SMK Negeri 03 Model Invest Kota Bengkulu dari aspek mekanik menggunakan teknik deskriptif, yaitu menghitung rata-rata tingkat kemampuan.

Data kemampuan siswa dalam menulis teks karangan narasi aspek mekanik kelas X SMK Negeri 03 Model Invest Kota Bengkulu pada aspek kalimat dapat dilihat pada tabel 9. Hasil kemampuan subjek penelitian yaitu di peroleh nilai rata-rata sebesar 5,17 Nilai tersebut bila dilihat pada kriteria penilaian aspek kesesuaian isi termasuk dalam kategori buruk sekali, karena terletak pada interval nilai 1-10. Dengan demikian, kemampuan siswa dalam menulis teks karangan narasi kelas X SMK Negeri 03 Model Invest Kota Bengkulu pada aspek mekanik termasuk dalam kategori buruh sekali.

Berdasarkan hasil perhitungan frekuensi pada tabel dan grafik dapat diketahui bahwa kemampuan siswa dalam menulis teks karangan narasi kelas $\mathrm{X}$ SMK Negeri 03 Model Invest Kota Bengkulu pada aspek mekanik terbagi atas: 13 nilai siswa termasuk kategori nilai buruk, dan 79 siswa termasuk dalam kategori nilai buruk sekali.

$$
\text { Hasil tes dilakukan cukup }
$$
maksimal, karena faktor yang dapat mempengaruhi hasil tes kemampuan menulis teks karangan narasi telah diatasi, seperti:

a. Pelaksanaan pengambilan data dilakukan pada saat jam kegiatan belajar mengajar berlangsung pada mata pelajaran Bahasa Indonesia. b. Ruangan pengambilan data cukup baik, karena dilengkapi dengan fasilitas proses belajar mengajar yang memadai dan pengaturan tempat duduk yang baik.

c. Suasana pengambilan data dilaksanakan dengan tenang. Siswa mengerjakan tugasnya dengan serius dan tertib.

\section{PENUTUP \\ Kesimpulan}

Berdasarkan hasil penelitian dapat disimpulkan bahwa kemampuan menulis teks karangan narasi siswa kelas $\mathrm{X}$ SMK Negeri 03 Model Invest Kota Bengkulu termasuk dalam kategori kurang. Maka dari itu, dapat dilihat dari nilai rata-rata sebesar 55,80. Berdasarkan tiap-tiap aspek adalah sebagai berikut:

1. Kemampuan menulis teks karangan narasi pada aspek isi mendapatkan hasil 17,82 pada interval 11-20 dengan kriteria buruk.

2. Kemampuan menulis teks karangan narasi pada aspek struktur teks mendapatkan hasil 12,24 pada interval 11-20 dengan kriteria buruk.

3. Kemampuan menulis teks karangan narasi pada aspek kosakata mendapatkan hasil 10,39 pada interval 1-10 dengan kriteria buruk sekali.

4. Kemampuan menulis teks karangan narasi pada aspek kalimat mendapatkan hasil 9,15 pada interval 1-10 dengan kriteria buruk sekali.

5. Kemampuan menulis teks karangan narasi pada aspek mekanik mendapatkan hasil 5,17 pada interval 1-10 dengan kriteria buruk sekali.

\section{Saran}

Berdasarkan hasil penelitian yang dilakukan, berikut penulis menyampaikan beberapa saran yang berkaitan dengan penelitian ini, 
1. Bagi siswa hendaknya lebih banyak berlatih menulis suatu teks, terutama teks narasi dan melihat pemilihan kosakata serta EYD dan tanda baca untuk meningkatkan kemampuan menulis teks narasi.

2. Bagi guru memberikan motivasi yang lebih kepada siswa dapat meningkatkan kemampuan belajar siswa serta memberikan pelajaran yang lebih pada aspek yang mendapatkan kategori cukup.

3. Bagi sekolah hendaknya menjadi pertimbangan untuk meningkatkan prestasi belajar mengajar dan mengetahui kemampuan siswa dalam menulis untuk meningkatkan motivasi siswa dalam berpretasi.

\section{DAFTAR PUSTAKA}

Abidin, Yunus. 2014. Desain Sistem Pembelajaran Dalam Konteks Kurikulum 2013. Bandung: Refika Aditama.

Fadillah, M. 2014. Implementasi Kurikulum $2013 \quad$ Dalam Pembelajaran SD/MI SMP/MTs SMA/MA. Yogyakarta: Ar-ruzz Media.

Kemendikbud. 2013. Buku Siswa Bahasa Indonesia Ekspresi Diri dan Akademik. Jakarta: Kementerian Pendidikan dan Kebudayaan.

Sugiyono. 2012. Metode Penelitian Kuantitatif Kualitatif \& R\&D. Bandung: Alfabeta. 